\title{
NEW ANTS FROM CHINA AND JAPAN
}

\author{
By William MoRToN WhEeleR
}

\section{Formicinæ}

Formica pratensis Retzius var. superba var. nov.

Worker. Length 5-6.5 mm.

Head, including the frontal area, thorax and abdomen opaque; mandibles and legs, including the coxæ, distinctly shining. Eyes not hairy. Erect hairs golden yellow, very few on the head, gula and promesonotum; border of petiole ciliate; gaster with sparse, blunt, apparently deciduous hairs ; pubescence grey, very fine, dense on the coxæ and legs; more dilute and not concealing the opaque surface on the gaster. Thorax and petiole rather rich red; mandibles dark brown; entire head, center of pronotum and anteromedian portion of mesonotum and the gaster deep black, decidedly darker than the similar regions in the typical pratensis of Europe, which are really dark brown or brownish black. First gastric segment with a large, transverse red spot just above the petiolar articulation; antennæ nearly black; legs dark brown, coxæ and trochanters somewhat paler and more reddish; border of petiole not infuscated.

Six specimens from Eastern Tomb, near Peking, China (Chi Ho).

Formica truncorum Fabr. var. approximans var. nov.

Worker. Very similar to the typical truncorum of Europe. Pilosity on the body and legs as abundant but of a bright golden yellow color, and on the tibiæ somewhat coarser though not longer than in the type. Color of head, thorax and petiole darker red; vertex and often also the middle of the promesonotum dark brown, even in large 
specimens; base of first gastric segment not yellowish red but dark brown like the remainder of the gaster.

Six specimens from Eastern Tombs, near Peking, China (Chi Ho).

Formica truncorum var. yessensis Forel

Six workers from Nankataigan, Formosa, collected by J. Sonan are really intermediate between the preceding form and sinensis Wheeler from Western China, the dorsal surface of the head and thorax being less hairy than in approximans and the typical truncorum and the tibiæ without oblique hairs, as in yessensis and sinensis.

Formica yoshiokæ sp. nov.

Worker. Length 4-6 mm.

Closely related to $F$. picea Nylander. Jet black; palpi, mandibles, antennæ, tarsi and articulations of legs deep piceous brown. Surface of the body, and especially of the gaster, even smoother and more shining than in picea; mandibles subopaque, densely and rather coarsely punctate-striate; clypeus and cheeks with very sparse, elongate, piligerous punctures. Head broader than in picea, epinotum of the same shape, in profile with straight and nearly horizontal base, forming a distinct obtuse angle with the declivity, which is straight, sloping and of the same length. Petiole with the superior border more compressed, more acute and distinctly notched in the middle. Hairs white, rather short, very sparse on the upper surface of the head and thorax and on the petiolar border; more numerous on the gaster, absent on the legs, which have only the usual row of bristles on the flexor surface of the tibiæ. Pubescence pale, distinct, but short and very dilute on the head, denser on the mesosterna and legs, lacking on the gaster.

Described from ten specimens taken by Mr. H. Yoshioka at an altitude of 1400 meters on Mt. Okagi, near Kiryu, Japan, July 26, 1932.

This ant may have to be regarded as a subspecies of picea. It differs, however, from the typical form, the subspecies orientalis Ruzsky and the five varieties described by him and Forel, in details of coloration and sculpture 
and from most of them in the shape of the epinotum and petiole.

\section{Dolichoderinæ}

Dolichoderus (Hypoclinea) quadripunctatus L. subsp. sibiricus Emery

Several workers taken by Mr. H. Yoshioka at Gummaken, Japan, July 17, 1930, agree closely with typical specimens of sibiricus in my collection from Tashkent, Turkestan (N. Kusnetzov). Emery states that the mandibles of this subspecies, which is slightly larger (3.5-3.8 $\mathrm{mm}$.) than the typical quadripunctatus, are not shining, but in this respect all of my specimens are like the European form, though somewhat more coarsely coriacious.

Heretofore no species of Dolichoderus has been taken in Japan. To Mr. Yoshioka belongs the credit of having added not only this but the following beautiful subspecies to the known ant-fauna of his native land.

Dolichoderus (Hypoclinea) quadripunctatus subsp.

yoshiokæ subsp. nov.

Worker. Length 2.8-3 mm.

Smaller than sibiricus and of the same size as the typical quadripunctatus. The sculpture is like that of sibiricus, but the surface of the head and thorax is more shining, apparently because the cavities of the numerous pits, or foveolæ are smoother and not so distinctly reticulate as in that subspecies. The color is different: Head, coxæ and gaster black; the paired spots on the first and second gastric segments ivory white, very large and sharply defined; thorax and petiole deep red, with the extreme base of the epinotum and anterior portion of the metapleuræ black; summit of petiolar node infuscated; mandibles, antennæ and legs yellowish red; a spot on the distal enlargement of the scapes and the distal portion of the funiculi fuscous; femora and tibiæ dark brown, except at their bases.

Described from ten workers taken by Mr. H. Yoshioka at Kiryu, Japan, Nov. 26, 1932. 

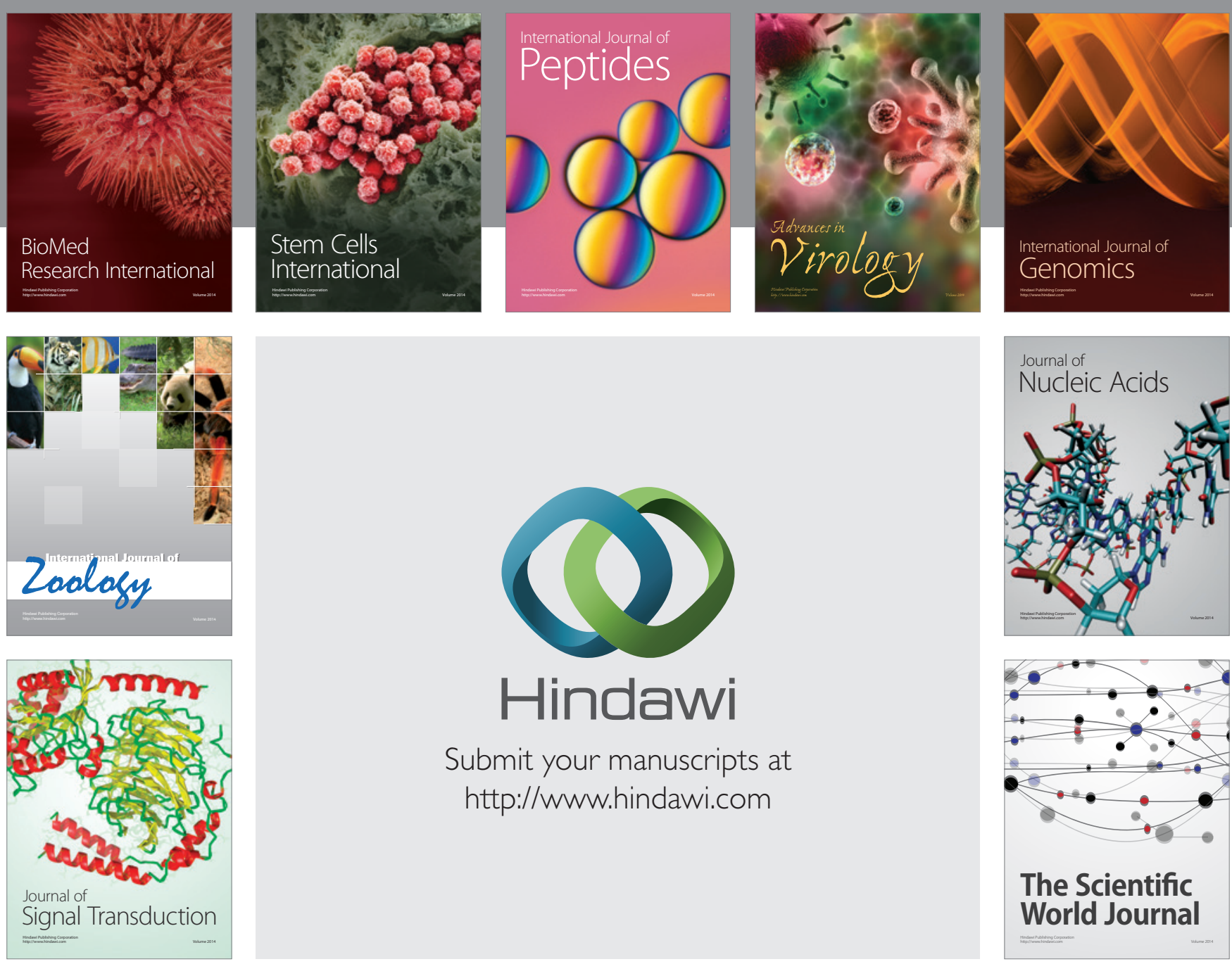

Submit your manuscripts at

http://www.hindawi.com
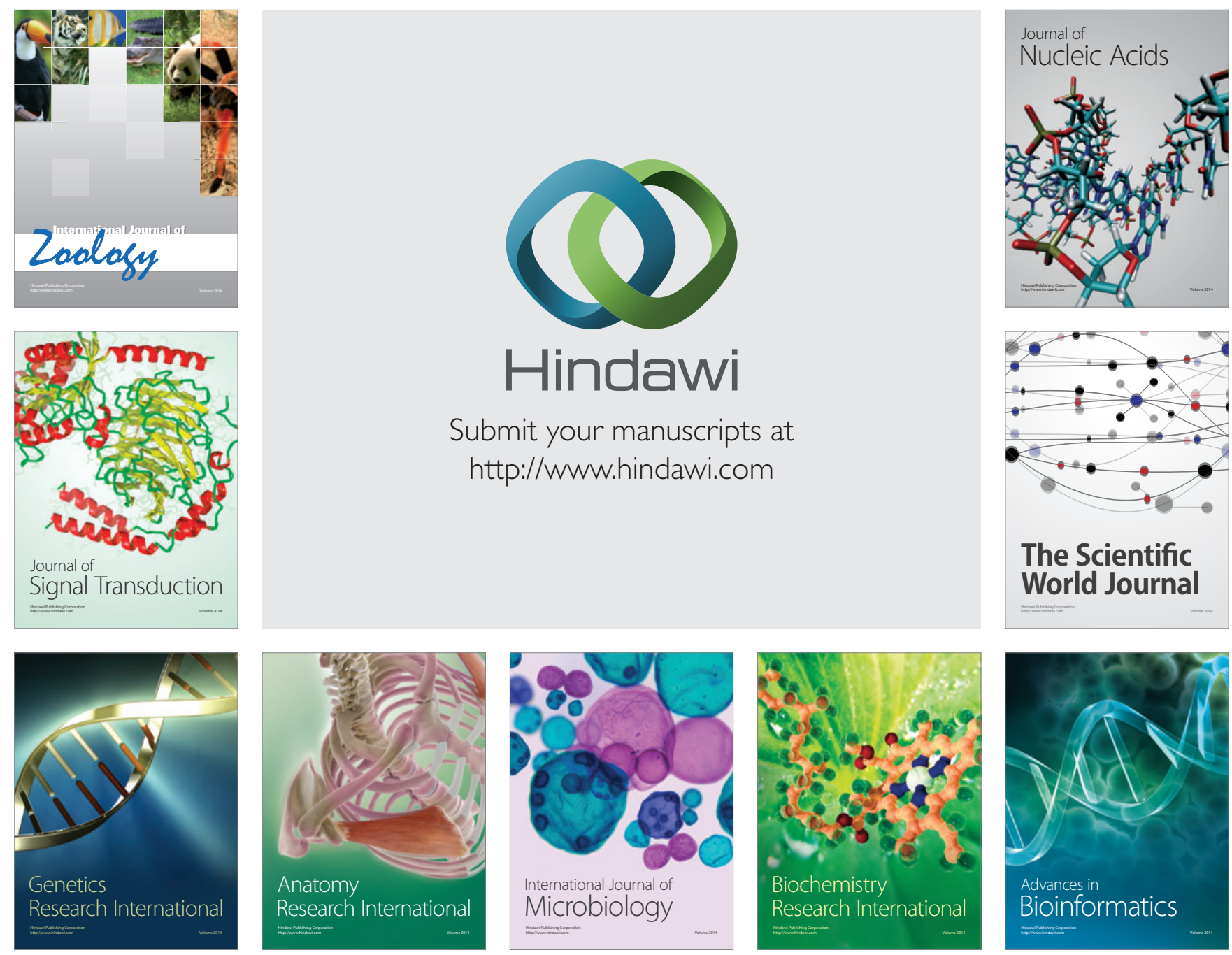

The Scientific World Journal
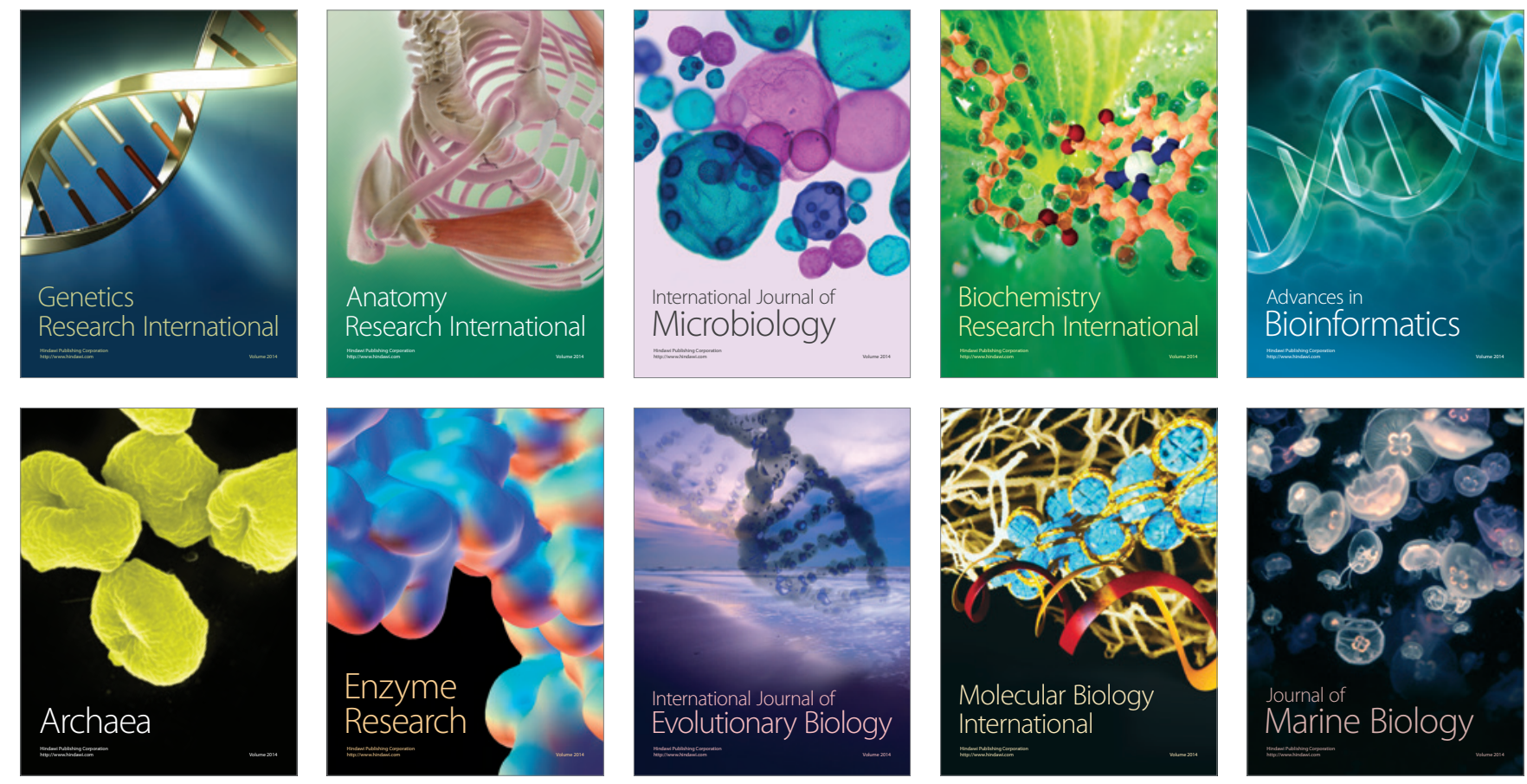